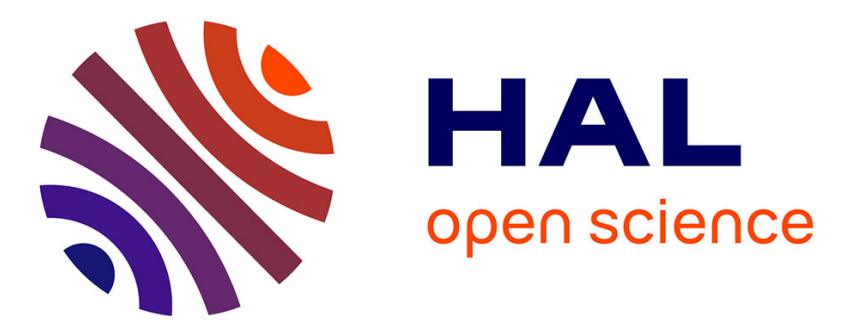

\title{
Asexual and puzzling sexual reproduction of the Mediterranean sponge Haliclona fulva (Demospongiae): life cycle and cytological structures
}

\author{
Alexander Ereskovsky, Alexia Geronimo, Thierry Perez
}

\section{To cite this version:}

Alexander Ereskovsky, Alexia Geronimo, Thierry Perez. Asexual and puzzling sexual reproduction of the Mediterranean sponge Haliclona fulva (Demospongiae): life cycle and cytological structures. Invertebrate Biology, 2017, 136 (4), pp.403-421. 10.1111/ivb.12195 . hal-01681599

\author{
HAL Id: hal-01681599 \\ https://hal.science/hal-01681599
}

Submitted on 19 Apr 2018

HAL is a multi-disciplinary open access archive for the deposit and dissemination of scientific research documents, whether they are published or not. The documents may come from teaching and research institutions in France or abroad, or from public or private research centers.
L'archive ouverte pluridisciplinaire HAL, est destinée au dépôt et à la diffusion de documents scientifiques de niveau recherche, publiés ou non, émanant des établissements d'enseignement et de recherche français ou étrangers, des laboratoires publics ou privés. 


\title{
Asexual and puzzling sexual reproduction of the Mediterranean sponge Haliclona fulva (Demospongiae): life cycle and cytological structures
}

\author{
A.V. Ereskovsky, ${ }^{1,2, a}$ A. Geronimo, ${ }^{1}$ and T. Pérez ${ }^{1}$ \\ ${ }^{1}$ Institut Méditerranéen de Biodiversité et d'Ecologie Marine et Continentale (IMBE), CNRS, \\ IRD, Aix Marseille Université, Avignon Université, Station Marine d'Endoume, 13007 \\ Marseille, France \\ ${ }^{2}$ Department of Embryology, Faculty of Biology, Saint-Petersburg State University, St. \\ Petersburg 199034, Russia
}

[footnote for first page]

aAuthor for correspondence. E-mail: alexander.ereskovsky@imbe.fr

\begin{abstract}
Despite the common assumption that most Haplosclerida are viviparous sponges, this study of the reproductive cycle of Haliclona fulva demonstrates that this species is actually oviparous and gonochoric. Intriguingly, not a single male was recorded in 15 months of sampling. Oogenesis is synchronous, starting in late April and terminating in September. Asexual reproduction is represented by cyclic budding, which occurs from late November to early March. During the season of asexual reproduction, the reproductive effort represents from $0.21 \%$ to $1.49 \%$ of the parental tissue, with the highest values being recorded in winter. During the season of sexual reproduction, the female reproductive effort ranges $0.05-1.15 \%$, with the highest effort appearing in early summer. However, no significant correlation between reproductive efforts and seawater temperature fluctuations could be detected. We describe the ultrastructural morphogenesis of the buds for the first time in this species. This process is asynchronous, with buds of variable size being attached to the maternal apical surface via a short stalk. Young buds lack any particular anatomical organization, whereas bud maturity is characterized by the development of mesohyl and by the appearance of an increasing number and volume of lacunae in the central part of each bud. At this stage, buds harbor numerous small choanocyte chambers scattered throughout the inner region, and all cell types known from the mesohyl of parental sponges: microgranular cells, granular cells, archaeocytes, endopinacocytes and exopinacocytes, central cells, and sclerocytes.
\end{abstract}

Additional key words: asexual reproduction, budding, Haplosclerida, oviparity, reproductive cycle

Knowledge of the life history and reproductive cycles of sponges is important for understanding their evolution, role in marine ecosystems, and to the understanding of marine population dynamics. In the past, investigations of the reproductive cycles of marine sponges have mainly dealt with the period of sexual reproduction. Although the dispersion and development of sponges in natural habitats is also supported by asexual reproduction, very few studies have considered the overall sponge life cycle and the alternation of sexual and asexual reproduction (Ayling 1980; Battershill \& Bergquist 1990; Wulff 1991; Corriero et al. 1996; Corriero et al. 1998; Plotkin \& Ereskovsky 1997). Indeed, asexual reproduction is an important 
reproductive strategy for sessile organisms such as sponges, and represents a significant evolutionary advantage that can compensate for the fact that mature adults are unable to move and search for mates. Sponge asexual reproduction may proceed by fragmentation, gemmulogenesis, and budding (Fell 1993; Simpson 1984; Ereskovsky 2010). For instance, budding occurs occasionally in almost all sponge clades and in any type of habitat (Fell 1993; Simpson 1984; Gaino et al. 2006; Ereskovsky \& Tokina 2007; Ereskovsky 2010; Teixido et al. 2006), but it is observed regularly among marine representatives of Porifera. For many Demospongiae of the orders Tethyida, Polymastiida, and Tetractinellida, budding represents a suitable reproductive strategy that enhances dispersal and colonization of the habitat (Sarà 1988; Bergquist \& Kelly-Borges 1991; Sarà et al. 1993; Gaino et al. 2006; Cardone et al. 2010). Some cases of obligatory asexual reproduction have been recorded in Spongillida, Tethyida, Clionaida, Suberitida, Polymastiida and Tetractinellida. For instance, gemmulogenesis occurs in all families of Spongillida (Ereskovskii 1999), except in Lubomirskiidae, and in the families Clionaidae (Clionaida) and Suberitidae (Suberitida) (Topsent 1888; Herlant-Meewis 1948; Hartman 1958; Connes 1977; Connes et al. 1978). Budding has been recorded in the families Polymastiidae and Tethyidae (Merejkowsky 1878, 1879; Connes 1967; Battershill \& Bergquist 1990; Chen et al. 1997; Plotkin \& Ereskovsky 1997; McDonald 2002; Gaino et al. 2006, 2009; Singh \& Thakur 2015).

When asexual reproduction exists in Demospongiae, the life cycle often presents a regular alternation of sexual and asexual phases (Ayling 1980; Pomponi \& Meritt 1990; Fell 1993; Corriero et al. 1996; Plotkin \& Ereskovsky 1997). Potential explanations for this alternation rely on the competition for cells between the two reproduction modes, especially for archaeocytes, which are likely polypotent cells (Korotkova 1988a). Archaeocytes are greatly involved in both oogenesis and embryogenesis, so a very low incidence or absence of asexual reproduction occurs during the season of sexual reproduction. This alternation can be seen as a trade-off between the two processes, and is thus in line with the hypothesis formulated by Korotkova (1988a,b) concerning the incompatibility of sexual and somatic morphogenesis, because they involve the same cell types.

In general, the initial stages of bud development in Demospongiae are represented by a dense conglomerate of cells at the parental sponge surface. At this stage, buds lack an aquiferous system, choanocyte chambers, canals, and oscula (Fell 1993). When the bud settles on the substrate, the aquiferous system starts to develop and the separated post-bud grows. Few studies have provided detailed information on the fine morphology and cytology of sponge buds (see Connes 1967; Ereskovsky \& Tokina 2007; Gaino et al. 2006, 2009), resulting in very incomplete knowledge of their cell composition. We hypothesized that further study would improve our understanding of the roles played by different cells in the formation of these asexual propagules.

Viviparity (brooding) and oviparity are widespread reproductive modes in Demosponges (Riesgo et al. 2013). Some orders are completely oviparous, like Polymastiida, Clionaida, Tethyida, and Verongida, while other orders have only viviparity, for example, Spongillida, Dendroceratida, and Dictyoceratida (Ereskovsky 2010). It is generally accepted that the families of order Haplosclerida (Morrow \& Cardenas 2015) display characteristic viviparity, with some oviparous species found in family Petrosiidae (Fromont \& Bergquist 1994).

In the Mediterranean Sea, information on sponge reproductive cycles and reproductive modes is already available for a number of Demospongiae from different clades (Siribelli 1962; Scalera Liaci et al. 1971; Corriero et al. 1996, 1998; Lepore et al. 2000; Meroz-Fine et al. 2005; Baldacconi et al. 2007; Mercurio et al. 2007; Riesgo \& Maldonado 2008; Piscitelli et al. 2011; 
Pérez-Porro et al. 2012; Di Camillo et al. 2012; Mercurio et al. 2013; Zarrouk et al. 2013; Reverter et al. 2016). However, there is less knowledge about the sponges from order Haplosclerida, which are relatively common and abundant in the Mediterranean Sea. Up to now, we have data on reproductive cycles for only four species of Haplosclerida (Scalera Liaci et al. 1973; Maldonado \& Riesgo 2009).

In this work, we investigate Haliclona fulva (TOPSENT 1893), a common shallow-water Mediterranean demosponge of the order Haplosclerida, family Chalinidae. We chose H. fulva for this study because this species regularly uses budding in its life cycle, unlike other haplosclerids, which have never been described to possess this mode of asexual reproduction. Moreover, as we show here, it is the only oviparous species in the family Chalinidae. We evaluate the incidence of sexual and asexual reproduction in the life cycle of Haliclona fulva and describe budding in $H$. fulva thoroughly, detailing the cellular composition of buds at different stages of development and comparing them with parental tissue.

\section{Methods}

\section{Biological model}

Haliclona (Halichoclona) fulva is a common Mediterranean sponge species, individuals of which form thick crusts (5-15 mm thickness) that vary in color from orange to red and which inhabit shaded benthic communities, such as semi-dark submarine caves or coralligenous formations, at depths of 5-50 m (Fig. 1A).

\section{Sampling site}

Sponges were collected by SCUBA diving at depths of between 14 and $16 \mathrm{~m}$ at a site called Grotte à Corail, located at Maire Island (Marseilles Bay). This sampling site was equipped with a permanent temperature recorder (HOBO Tidbit Data Logger). From September-March 2007 to December 2008, between four and nine individuals were collected monthly (during June and August 2008, the sponges were sampled twice), which represents a total of 103 individuals studied (Table 1). Only one month (October 2007) could not be sampled due to bad weather conditions. In order to pinpoint the period of budding, we also examined a great number of underwater photographs taken by scientific divers at different sites in the Marseille region from 1999 to 2009.

\section{Morphological and ultrastructural analysis}

To characterize the life cycle and assess the reproductive effort, samples were preserved in Bouin's fixative. Tissue fragments were then dehydrated through an ethanol series and embedded in paraffin. Serial sections of $6 \mu \mathrm{m}$ thickness were mounted on glass slides and stained with Masson-Goldner's trichrome hematoxylin, and then observed under a WILD M20 light microscope.

For semithin sections and for transmission electron microscopy (TEM) investigations, sponges were fixed in a solution composed of one volume of $25 \%$ glutaraldehyde, four volumes of $0.2 \mathrm{M}$ cacodylate buffer, and five volumes of filtered seawater for $2 \mathrm{~h}$ before being post-fixed in $2 \% \mathrm{OsO}_{4}$ in seawater at room temperature for $2 \mathrm{~h}$. After fixation, samples were washed in 0.2 $\mathrm{M}$ cacodylate buffer and distilled water successively, and finally dehydrated through a graded ethanol series. Specimens were embedded in Araldite resin. Semithin sections $(1 \mu \mathrm{m}$ in thickness) were cut on a Reichert Jung ultramicrotome equipped with a "Micro Star" $45^{\circ}$ diamond knife before being stained with toluidine blue, and observed under a WILD M20 
microscope. Digital photos were taken with a Leica DMLB microscope using the Evolution LC color photo capture system. Ultrathin sections $(60-80 \mathrm{~nm})$ were cut with a Leica UCT ultramicrotome equipped with a Drukkert $45^{\circ}$ diamond knife. Ultrathin sections, contrasted with uranyl acetate, were observed under a Zeiss-1000 transmission electron microscope (TEM).

\section{Data analysis}

Calculations of sexual reproductive effort (sRE) were carried out on serial histological sections. For each specimen, digital photographs of 16 histological sections were analyzed. Four photographs per serial section were taken. To avoid the overlapping of reproductive products that would lead to over-estimation, photographs of tissue were taken at least $200 \mu \mathrm{m}$ from each other. The four photographs provided a total surveyed area of $1 \mathrm{~mm}^{2}$ per sponge. We determined the number of sexually active sponges over time, counted the number of reproductive elements, and calculated the area of each reproductive element within the tissue sample, using ImageJ Software (http://rsb.info.nih.gov/ij/index.html). Reproductive elements were related to the overall surface of the section, and reproductive effort could thus be expressed as a percentage of reproductive tissue (mean $\pm \mathrm{SD}$ ).

In order to calculate the number of asexual reproductive efforts (aRE), the number of buds per individual was counted and bud area was estimated. These data allowed us to obtain the total surface of buds relative to the sponge surface, with aRE also expressed as a percentage of reproductive tissue.

The nonparametric Kruskal-Wallis test was used to determine the seasonal variability of each reproductive effort. To assess the putative influence of seawater temperature, we then applied a Spearman correlation test. Statistics and graphs were performed using RStudio (R Development Core Team, 2012 ).

\section{Results \\ Reproductive cycle}

No occurrence of gametogenesis was found between November 2007 and April 2008, nor from November to December 2008. In 2008, we observed oogenesis starting in late April and ending in September (Table 1, Fig. 2). No hermaphroditic individuals were observed; thus, Haliclona fulva appears to be gonochoric and oviparous, given the absence of observable embryo development. Through examination of our sponge collection and in situ photographs, we were able to observe the beginning of the budding period of H. fulva in early November and the end in April (Table 1, Fig. 2), which indicates an alternation between sexual and asexual processes.

\section{Sexual reproduction}

No male reproductive elements were recorded during this study of 103 individuals collected from this subpopulation. Of the 44 individuals observed during this period, 7 individuals lacked reproductive elements, but not a single male was recorded.

Oocytes were observed throughout the mesohyl, with the exception of the most superficial layer of the sponge tissue below the exopinacoderm. Oogenesis was synchronous within a mother sponge and in the entire population. Young oocytes were of small size, 14-24 $\mu \mathrm{m}$ in diameter. At this previtellogenic stage, oocytes (35-47 $\mu \mathrm{m}$ in diameter) had an irregular shape, a consequence of their active movement in the maternal mesohyl and phagocytosis of amoebocytes (Fig. 3A,B). During vitellogenesis, oocytes increased significantly in size to reach $50-77 \mu \mathrm{m}$ in diameter. When the yolk started to accumulate, the oocytes amassed near exhalant 
canals (Fig. 3C,D). At this stage, they were surrounded by a follicle. At the end of oogenesis, the eggs penetrated into the exhalant canals to be released into the seawater column through the aquiferous system.

\section{Reproductive effort}

The calculation of monthly mean sexual reproductive effort (sRE) was possible for females only and revealed significant variation over time (Kruskal-Wallis test: $\chi^{2}=24.40$, $\mathrm{K}=24.28, \mathrm{df}=8, \mathrm{p}=0.002$ ), with a minimum of $0.05 \%$ in April 2007 and a maximum of $1.15 \%$ in late August 2008 (Fig. 4A). Furthermore, the observed interannual variation is supported by a significant difference between sRE in September 2007 (2.70\%) and September $2008(0.44 \%)$ (Mann-Whitney-Wilcoxon: $\mathrm{U}=3, \mathrm{p}=0.009$ ).

The calculation of asexual reproductive effort (aRE) revealed a minimum of $0.21 \%$ for March 2008 and a maximum of 1.49\% for January 2008 (Fig. 4B). We used the Kruskal-Wallis test to compare median aRE values for January, February and March, which showed that the

apparent differences were not significant $\left(\chi^{2}=3.84, \mathrm{~K}=3.84, \mathrm{df}=2, \mathrm{p}=0.147\right)$. A Spearman correlation statistic was used to quantify the association between reproductive effort and temperature fluctuations. No significant correlation could be detected between temperature fluctuations and either sRE or aRE (Spearman rank correlation: $r=0.130, p=0.843$; and $r=0, p=1$, respectively).

\section{Morphological observations of budding}

Buds were mostly concentrated on the central part of the sponge surface (Fig. 1B). They were attached to the maternal apical surface by a short stalk (Fig. 5A), and were of different sizes and shapes due to their asynchronous development. Buds were oval or spherical, their mean surface was $0.5 \mathrm{~mm}^{2}$ and their diameter ranged $0.5-3 \mathrm{~mm}$ (Fig. 5A,B). Their density also differed among specimens.

The beginning of budding was marked by the formation of small, irregular protuberances that emerged from the sponge surface. The buds then grow gradually as their apical region swelled (Fig. 5A,B). Bud skeletons consisted of oxea arranged uniformly at the periphery of the bud and in the mesohyl, but at this early stage of development the bud surface remained smooth. At the histological level, early buds did not possess any particular anatomical organization: there was no developed ectosome or choanosome (Fig. 5C). They consisted of a mass of compact cells, with a higher density of cells in the central part than at the periphery (Fig. 5C). Cells with inclusions (microgranular, granular cells), as well as cells with irregular shapes and long, thin cytoplasmic extensions (lophocytes, archaeocytes), were uniformly distributed throughout the bud tissue.

Just before their detachment, the external morphology and anatomy of mature buds changed. At this stage, buds clearly protruded from the sponge surface. They were oval in shape and had a pleated surface. Their central part slackened due to a significant increase in the number and volume of internal lacunae. Meanwhile, the mesohyl developed with a synthesis of collagen bundles and spicules (Fig. 5D). In contrast with the early stage, many small choanocyte chambers, composed of a few choanocytes and a central cell, were scattered through the inner region of the buds (Fig. 5D).

\section{Cytological composition of the buds}


Many choanocytes could be observed in aggregates in the central part of young buds, but at this stage of development, they did not yet form choanocyte chambers (Figs. 5C, 6A). These cells were spherical or oval and measured about $3.2 \mu \mathrm{m}$ in width and $4.3 \mu \mathrm{m}$ in height. Their nucleus was oval $(\sim 1.5 \mu \mathrm{m}$ in diameter), lacked a nucleolus, but featured prominent heterochromatin (Fig. 6A). In mature buds, choanocyte chambers measured 15-18.5 $\mu \mathrm{m}$ in diameter (Figs. 5D, 6B).

The central cells were large amoeboid-like cells that were present inside of each choanocyte chamber (Fig. 6B,C). The central cells were irregular and branched in shape and had numerous cytoplasmic projections. Their nucleus was large (2.3-2.9 $\mu \mathrm{m}$ in diameter), spherical, and without a nucleolus. The cytoplasm of these cells was perforated by one large canal $(1.8 \times 3.5$ $\mu \mathrm{m}$ in diameter) and other, smaller, canals $(\sim 0.5 \mu \mathrm{m}$ in diameter) into which entered the flagellum of each choanocytes in the chamber (Fig. 6C).

The buds and the stalk were covered with an exopinacoderm composed of exopinacocytes, which were flat cells $(\sim 17.8 \mu \mathrm{m}$ wide and $5.1 \mu \mathrm{m}$ high) that harbored an oval anucleolated nucleus $(5.0 \times 2.6 \mu \mathrm{m}$ in diameter) (Figs. 5C, 7A).

Microgranular cells with small inclusions had an amoeboid, slightly irregular shape $(\sim 8.5 \times 4.9 \mu \mathrm{m})$, with a nucleus of $1.8 \mu \mathrm{m}$ in diameter (Fig. 7B). These cells had vacuoles measuring 1-1.5 $\mu \mathrm{m}$ in diameter, with small, electron-dense inclusions. Microgranular cells were more numerous at the periphery of the buds (where they represented $\sim 30 \%$ of total cells) than in the central part (where they represented only 8\%) (Fig. 5C,D).

Granular cells had an oval or amoeboid shape $(\sim 9.5 \mu \mathrm{m}$ in diameter) and harbored an anucleolated nucleus and large, homogenous electron-dense inclusions which were spherical in shape (1.2-2.7 $\mu \mathrm{m}$ in diameter) (Figs. 5C, 7C). These cells were less numerous than the previous cell type.

Archaeocytes were amoeboid or spheroid cells with no particular inclusions $(\sim 8.2 \mu \mathrm{m}$ wide and $4.6 \mu \mathrm{m}$ high). These cells were also abundant and harbored a large nucleus $(2.5 \mu \mathrm{m}$ in diameter) and a prominent nucleolus (Fig. 7D). Another amoeboid cell was the lophocyte. They were the biggest cells found in the buds $(\sim 18 \mu \mathrm{m}$ wide and $5 \mu \mathrm{m}$ high), with a large oval nucleus $(4.5 \times 2.5 \mu \mathrm{m})$ that may have had a nucleolus (Fig. 7E). The cytoplasm of lophocytes contained different sorts of inclusions such as granules and phagosomes, and these cells presented a developed, rough endoplasmic reticulum.

Sclerocytes were oval or amoeboid cells $(\sim 7.0 \mu \mathrm{m}$ in diameter) with a large vacuole (Fig. 7F). Endopinacocytes were flat cells $(\sim 19.6 \mu \mathrm{m}$ wide and $3.0 \mu \mathrm{m}$ high) with an oval nucleus $(4.2 \times 2.0 \mu \mathrm{m})$ and no nucleolus, and the cytoplasm of these cells included numerous vacuoles (Fig. 7G). These cells formed the canals of the aquiferous system at the late stage of bud development. Collagen fibrils were quite abundant in the central part of the bud where they were sometimes arranged in fine bundles; they were, however, rare at the periphery. Finally, many extracellular symbiotic bacteria were found in the mesohyl (Figs. 6A,B; 7B,F).

\section{Discussion}

It is considered that asexual reproduction together with sexual reproduction accompanied multicellular animals throughout their entire evolution. Asexual reproduction in one form or another has repeatedly appeared and disappeared in different groups of Metazoa (Ivanova-Kazas 1977; Adiyodi \& Adiyodi 1993). In some animals, such as flatworms, annelids, and holothurians (Christensen 1984; Franke 1999; Reuter \& Kreshchenko 2004; Dolmatov 2014), asexual reproduction is a sporadic process. In other organisms with mixed life history strategies, such as 
most cnidarians, tunicates, bryozoans and some sponges, asexual reproduction is an obligatory stage of their life cycle (Ivanova-Kazas 1977; Adiyodi \& Adiyodi 1993; Brusca 2016). In the latter case, sexual reproduction can be an adaptive advantage in unstable or unpredictable environments, while asexual reproduction is the competitively superior tactic for colonization of the parental environment (Williams 1975; Maynard Smith 1978).

According to the available limited data, budding might promote the maintenance and growth of marine sponge populations (Corriero et al. 1996; Corriero et al. 1998; Cardone et al. 2010; Singh \& Thakur 2015). Indeed, buds have been shown to contribute significantly to the dispersal and recruitment of new sponges (Wulf 1995), in particular under conditions of environmental stress. This strategy thus may improve the survival of individual sponge genotypes, and enhance the growth of a sponge population, as is the case for clonal organisms (Jackson \& Coates 1986).

\section{Reproductive pattern}

Viviparity (brooding) is more widespread and perhaps an ancestral reproductive mode in Porifera (Riesgo et al. 2014). However, oviparity is the general rule in the Demospongiae orders Tetractinellida, Polymastiida, Suberitida, Clionaida, Tethyida, Chondrosida, Verongida, Agelasida, Biemnida, and Axinellida (Ereskovsky 2010). Viviparous representatives are found in some these orders, however; these representatives include, for example, the viviparous genera Alectona and Thoosa (order Suberitida), genus Stylocordyla (order Suberitida), and genus Halisarca (order Chondrosida) (Vacelet 1999; Sarà et al. 2002; Bautista-Guerrero et al. 2010; Ereskovsky \& Gonobobleva 2000). It is largely accepted today that these two reproductive traits do not have any phylogenetic value and cannot be used for taxonomical revision of Porifera (Hoppe 1988; van Soest 1991; Ereskovsky 2010; Riesgo et al. 2014).

The studies by Fromont (1994a, b) and Fromont and Bergquist (1994) led to the general acceptance that all Haplosclerida families are characterized by viviparity, with the only exception being the oviparity in some Petrosiidae (Table 2). Although a good number of representatives of Chalinidae, especially in the Haliclona genus, have been shown to be viviparous, the present work demonstrates surprisingly that the Mediterranean Haliclona fulva is oviparous.

Another feature of the life cycle of $H$. fulva that is unusual in Haplosclerida is that this species includes budding as an obligatory phase of asexual reproduction, alternating with a sexual one. This case once more supports the observations that budding in Demospongiae is correlated with oviparity (Fell 1993; Ereskovsky 2010). Up to now there are only two exceptions to this rule: the viviparous demosponges Mycale (Aegogropila) contarenii (LIEBERKÜHN 1859) (Poecilosclerida) (Corrierro et al. 1998) and Radiospongilla cerebellata (BOWERBANK 1863) (Spongillida) (Saller 1990).

While different modes of reproduction often occur within the same genus in various marine metazoans, for instance in Echinodermata and Bivalvia (Strathmann 1978; Kasyanov 2001; Byrne et al. 2003), in sponges this phenomenon has previously been observed only in two genera of Petrosiidae (Haplosclerida). In the genus Xestospongia, X. bergquistia FromONT 1991, X. testudinaria (WILSON 1925), and X. muta (SCHMIDT 1870) are oviparous, releasing sperm and eggs, while $X$. bocatorensis DiAZ, THACKER, RÜTZLER \& PIANTONI, 2007 is viviparous, releasing brooded larvae (Fromont \& Bergquist 1994; Becerro 2005; Collin et al. 2010). In the genus Neopetrosia, N. exigua (KIRKPATRICK 1900) is oviparous, while N. proxima (DUCHASSAING \& MichelotTI 1864) is viviparous (Fromont \& Bergquist 1994; Collin et al. 2010). 
Another explanation for the phenomenon of oviparity in Haliclona fulva and different reproductive patterns in Xestospongia and Neopetrosia follows from the systematics of the order Haplosclerida. The phylogenetic relationships among haplosclerids are not clear yet, and suggestions of the polyphyletic nature of the various taxa within this order have appeared in various publications (Hill et al. 2013; McCormack et al. 2002; Raleigh et al. 2007; Redmond et al. 2007; Redmond et al. 2011; Redmond et al. 2013). It is important that the biggest genus Haliclona is distributed across the order Haplosclerida. Redmond et al. (2013) showed that members of this genus are positioned within Clade $\mathrm{C}$ with Niphatidae and Petrosiidae. The latter family, as mentioned above, includes both oviparous and viviparous species, particularly the viviparous Neopetrosia proxima (Collin et al. 2010) in Clade C. Species of Haliclona are also positioned within Clade B and has high support for a sister relationship with the viviparous Xestospongia bocatorensis (Collin et al. 2010). It should be noted that this Clade B also includes the oviparous X. muta. According to the results of Redmond et al. (2011), H. fulva is located in the cluster including the oviparous Petrosia ficiformis (POIRET 1789) and three other Petrosia species, as well as H. mucosa (GRIESSINGER 1971) and Cribrochalina vascuum (LAMARCK 1814). Therefore, it is possible that $H$. fulva might be misplaced in the genus Haliclona, and relationships with other oviparous clades might be the key to understanding reproductive behavior in $H$. fulva.

The general pattern of $H$. fulva oogenesis is similar to that reported for other oviparous Haplosclerida: no degeneration of mesohyl is observed during oogenesis and the majority of the eggs that develop to maturity retain an ovoid shape (Fromont 1988; Lepore et al. 1995; Maldonado \& Riesgo 2009). During vitellogenesis, the oocytes have an amoeboid shape and participate in the phagocytosis of somatic cells, rich of phagosomes, like other investigated Haplosclerida (Ereskovsky 2010).

It is always a challenge to describe the reproductive cycle of oviparous sponges, but it is even more difficult when the males are hidden. Despite the large number of specimens of $H$. fulva investigated, no spermatocysts were observed. A very low ratio of male : female individuals has been reported for many marine sponges (Hogg 1967; Scalera Liaci et al. 1971; Ayling 1980; Corriero et al. 1996; Corriero et al. 1998; Mercurio et al. 2007; Ereskovsky et al. 2013). For example, after two years of fortnightly monitoring, Ayling (1980) found males of Aaptos aaptos (SCHMIDT 1864) in only one year of the study. No males were found in Mediterranean oviparous sponges Tethya citrina SARA \& MELONE 1965 and T. auranrium (PALLAS 1766) during monthly collection over an 18-month period (Corriero et al. 1996). In a striking parallel to our study of H. fulva, the same author was unable to detect a single male among populations of Raspailia topsenti DENDY 1924 and Polymiastia sp. over a 2-year monitoring period (Ayling 1980).

Giesel (1972) proposed that deviations in sex ratio may internally regulate the size of a population by affecting its reproductive potential. In brooding corals, for example, female biased sex ratios may be an evolutionary adaptation caused by the physical limitations of the incubation chamber inside of polyps (Szmant 1986). Whalan et al. (2007) discussed some possible problems that may lead to biased sex ratios in sessile or slow moving marine invertebrates: proximity to mates (Sewell \& Levitan 1992; Babcock \& Keesing 1999), sperm limitation (Brazeau \& Lasker 1992), and dilution of gametes (Oliver \& Babcock 1992). Other possible factors that could influence the sex ratio are temperature, salinity, and the quantity and quality of food available (Simonini \& Prevedelli 2003). 
In this study of $H$. fulva, we remain perplexed as to where the males are. One explanation for the absence of males could be that the species has a very short period of spermatogenesis. In demosponges the period of spermatogenesis often is shorter compared to oogenesis (Ayling 1980; Diaz 1979; Ereskovsky 2000; Riesgo \& Maldonado 2008; Mercurio et al. 2007; Whalan et al. 2007; Ereskovsky et al. 2013; Stephens et al. 2013). This trend is more pronounced in oviparous sponges, particularly in oviparous Haplosclerida. For example, in Xestospongia bergquistia and X. testudinaria from the Great Barrier Reef, the period of oogenesis lasts more than 5 months, while spermatogenesis lasts less than 5 days (Fromont \& Bergquist 1994). In Mediterranean Petrosia ficiformis, oogenesis duration is 7-8 months, and the duration of spermatogenesis is only 2-2.3 weeks (Scalera Liaci et al. 1973; Maldonado \& Riesgo 2009). Corriero et al. $(1996,1998)$ proposed that a very short period of spermatogenesis accounted for the absence of males during monthly collections of Tethya citrina, T. auranrium, and Mycale contarenii over 18 months of monitoring. Thus, it's possible to assume that the nine individuals of Haliclona fulva that lacked any reproductive elements (of the 37 individuals observed during the period of oogenesis) could be males with a short spermatogenesis period.

\section{Reproductive cycle and effort}

Numerous external factors could be responsible for induction of sexual or asexual reproduction in individuals within a population of heterogonic invertebrate species. Among the more important are the physicochemical quality of water, hydrodynamic, food availability, population density, habitat stability, and seasonal variation in temperature (for review see: Adiyodi \& Adiyodi 1993). Nevertheless, it seems that water temperature and food availability play the principal roles in this process in the case of various marine invertebrates, such as sea anemones (Bucklin 1987), scyphozoans (Lucas et al. 2012; Purcell et al. 2012), echinoderms (Lawrence \& Herrera 2000), and bryozoans (O'Dea 2006). In sponges, the increase in the frequency of specimens with buds and in the number of buds per sponge happens concomitantly with rapid decreases in water temperature as, for example, in the Mediterranean species Tethya citrina T. aurantium, Mycale contarenii (Connes 1968; Corriero et al. 1998; Cardone et al. 2010) and in White Sea species Polymastia arctica (MEREJKOWSKY 1878) (Plotkin \& Ereskovsky 1997). In H. fulva, budding takes place from late November to early March, which is the coldest season. This is also the case for the two Mediterranean Tethya citrina and T. aurantium (Connes 1968; Corriero et al. 1996; Gaino et al. 2006) and Mycale contarenii (Corriero et al. 1998). However we were unable to demonstrate a significant correlation between the natural variations of seawater temperature and asexual reproductive effort.

Reproductive effort is an integrative indicator of resource allocation to reproductive compartments, and it can vary greatly depending on the reproductive strategy. Haliclona fulva allocates energy to the differentiation of gametes or buds at very different times, and as in other marine sponges, there is a clear alternation of sexual and asexual phases of reproduction (Fell et al. 1979; Corriero et al. 1996; Corriero et al. 1998). Both reproductive efforts are of roughly the same intensity, with oogenesis representing $0.7 \%$ on average over the period, and budding representing $0.9 \% H$. fulva demonstrates low annual variability of both reproductive processes, whereas marine organisms can exhibit highly variable sexual or asexual reproductive efforts which are sometimes related to the natural variations of the sea water temperature (Adiyodi \& Adiyodi 1993; Olive 1995; Llodra 2002). Overall, biotic and abiotic factors that regulate the proportion of asexual and sexual reproduction in the life cycle of heterogonic species are poorly understood. Unfortunately, in the case of $H$. fulva we were unable to fill this knowledge gap. 
Although our sampling strategy has proven its efficiency in a number of previous studies of sponge life cycles (see for instance Pérez et al. 2011; Ivanisevic et al. 2011a, b; Ereskovsky et al. 2013; Zarrouk et al. 2013; Reveter et al. 2016), we are here confronted with a limitation with this strategy for H. fulva.

\section{Bud formation, structure and cell composition}

The development of buds differs among sponge species. For example, the formation of the aquiferous system can occur either during bud development (Saller 1990; Ereskovsky \& Tokina 2007; Gaino et al. 2009; this work), or after detachment from the parental sponge (Ayling 1980; Battershill \& Bergquist 1990; Gaino et al. 2006).

Haliclona fulva presents three stages in its bud formation: an ectosomal protuberance caused by cell migration; growth of the apical part of the bud with formation of the stalk connected to the parental sponge; and thin-stalked buds protruding noticeably from the sponge surface, followed by detachment of the bud. These stages are very similar to what was described in Tethya aurantium (Connes 1968; Gaino et al. 2006), Radiospongilla cerebellata (Saller 1990), T. seychellensis (WRIGHT 1881) (Gaino et al. 2009), and in Cinachyrella cavernosa (LAMARCK 1815) (Singh \& Thakur 2015).

Cells in buds are amoeboid-like in shape and show cytoplasmic extensions. They tend to align either in parallel rows or along the spicule bundles. These features suggest that these cells may be able to migrate from the parental sponge to the newly formed buds. The migration of specialized and polypotent cells, and their subsequent differentiation into definitive cells, is a typical feature of the budding process (Ereskovsky 2003, 2010; Gaino et al. 2006). In this work we have shown that unreleased buds of $H$. fulva possess choanocyte chambers. The occurrence of choanocyte chambers is very uncommon in demosponge buds. Until now, these structures have been observed in unreleased buds of only four demosponge species: in Mycale contarenii (Devos 1965; Corriero et al. 1998), in the freshwater sponge Radiospongilla cerebellata (Saller 1990), in Tethya seychellensis (Gaino et al. 2009), and in T. wilhelma SARA, SARA, NICKEL \& BRÜMMER 2001 (Hammel et al. 2009), as well as in homoscleromorph sponges of the genus Oscarella (Ereskovsky \& Tokina 2007).

Cell composition in demosponge buds has been poorly studied. Optic microscopy has provided only two good descriptions of bud cell composition in Mycale contarenii and Axinella damicornis (ESPER 1794) (Devos 1965; Boury-Esnault 1970), and electron microscopy has illustrated this condition in Tethya aurantium, T. citrina, T. seyshellensis, Radiospongilla cerebellata, and Cinachyrella australiensis (CARTER 1886) (Connes 1967, 1968; Saller 1990; Chen et al. 1997; Gaino et al. 2006, 2009). According to these descriptions, it seems that cells with inclusions represent the main cellular components of buds, and that archaeocytes are the second most abundant cell type observed. In A. damicornis, $M$. contarenii, and $R$. cerebellata, all cell types of the parental sponge are present in equal proportions in the buds at their later developmental stages (Devos 1965; Boury-Esnault 1970; Saller 1990). In this respect, the buds of H. fulva do not differ from these sponges, as they are composed of microgranular cells, granular cells, archaeocytes, endopinacocytes (and exopinacocytes), choanocytes, central cells, and sclerocytes. On average, all these cells are similar in size to the cells of the parental sponge. Further research is needed to determine whether cell inclusions represent stored material useful in sustaining morphogenetic processes (Connes 1967), and whether they might thus be pivotal for the acquisition of complete functionality. 
Acknowledgments. This work has been supported by grant $\mathrm{n}^{\circ}$ 1.38.209.2014 from SaintPetersburg State University, and the Russian Science Foundation \#17-14-01089 (for the microscopy). The authors gratefully thank Joël Courageot and Alexandre Altié of Service Commun de Microscopie Électronique et Photographie Faculté de Médecine La Timone, AixMarseille Université and Daria Tokina for technical support.

\section{References}

Adiyodi KG \& Adiyodi RG, eds. 1993. Reproductive biology of invertebrates. 6 A: Asexual propagation and reproductive strategies. Oxford \& IBH publishing Co., New Delhi: 456 pp.

Amano S 1988. Morning release of larvae controlled by the light in an intertidal sponge, Callyspongia ramosa. Biol. Bull. 175: 181-184.

Ayling AL 1980. Patterns of sexuality, asexual reproduction and recruitment in some subtidal marine Demospongiae. Biol. Bull. 158: 271-282.

Babcock RC \& Keesing J 1999. Fertilisation biology of the abalone Haliotis laevigata: laboratory and Weld studies. Can. J. Fish. Aquat. Sci. 56: 1668-1678.

Battershill CN \& Bergquist PR 1990. The influence of storms on asexual reproduction, recruitment, and survivorship of sponges. In: New Perspectives in Sponge Biology. Rützler K, ed., pp. 397-403. Smithsonian Inst, Press, Washington.

Becerro MA 2005. Spawning of the giant barrel sponge Xestospongia muta in Belize. Coral Reef 24: 160.

Bautista-Guerrero E, Carballo JL, \& Maldonado M 2010. Reproductive cycle of the coralexcavating sponge Thoosa mismalolli (Clionaidae) from Mexican Pacific coral reefs. Invert. Biol. 129: 285-296.

Bergquist PR \& Kelly-Borges M 1991. An evaluation of the genus Tethya (Porifera: Demospongiae: Hadromerida) with description of new species from the Southwest Pacific. Beagle 8: 37-72.

Boury-Esnault N 1970. Un phénomène de bourgeonnement externe chez l'éponge Axinella damicornis (Exper.). Cah. Biol. Mar. 11: 491-496.

Brazeau DA \& Lasker HR 1992. Reproductive success in the Caribbean octocoral Briareum absestinum. Mar. Biol. 114: 157-163.

Brusca RC 2016. Unvertebrates. Sinauer Associates, Inc., Sunderland. 1052 pp.

Bucklin A 1987. Growth and asexual reproduction of the sea anemone Metridium: comparative laboratory studies of three species. J. Exp. Mar. Biol. 110: 41-52.

Byrne M, Hart MW, Cerra A, \& Cisternas P 2003. Reproduction and Larval Morphology of Broadcasting and Viviparous Species in the Cryptasterina Species Complex. Biol. Bull. 205: 285-294.

Cardone E, Gaino E \& Corriero G 2010. The budding process in Tethya citrina Sar. \& Melone (Porifera, Demospongiae) and the incidence of post-buds in sponge population maintenance. J. Exp. Mar. Biol. 389: 93-100.

Chen YH, Chen CP, \& Chang KH 1997. Budding cycle and bud morphology of the globeshaped sponge Cinachyra australiensis. Zool. Stud. 36: 194-200.

Christensen B 1984. Asexual propagation and reproductive strategies in aquatic Oligochaeta. Hydrobiologia 115: 91-95. 
Collin R, Mobley AS, Lopez LB, Leys SP, Diaz MC, \& Thacker RW 2010. Phototactic responses of larvae from the marine sponges Neopetrosia proxima and Xestospongia bocatorensis (Haplosclerida: Petrosiidae). Invert. Biol. 129: 121-128.

Connes R 1967. Structure et développement des bourgeons chez l'éponge siliceuse Tethya lyncurium Lamarck. Arch. Zool. Exp. Gén. 108: 157-195.

Connes R 1968. Etude histologique, cytologique et expérimentale de la régénération et de la reproduction asexuée chez Tethya lyncurium Lamarck (= Tethya aurantium (Pallas) (Demosponges). D. Phil. Thesis, Université Montpellier, 193 pp.

Connes R 1977. Contribution a l'Etude de la gemmulogenese chez la d'éponge marine Suberites domuncula (Olivi) Nardo. Arch. Zool. Exp. Gén. 118: 391-407.

Connes R, Carriere D, \& Paris J 1978. Etude du developpement des gemmules chez la demosponge marine Suberites domuncula (Olivi) Nardo. Ann. Sci. Nat. Biol. Anim. Paris 20: $357-387$.

Corriero G, Sarà M, \& Vaccaro P 1996. Sexual and asexual reproduction in two species of Tethya (Porifera: Demospongiae) from a Mediterranean coastal lagoon. Mar. Biol. 126: 175-181.

Corriero G, Scalera Liaci L, Nonnis Marzano C, \& Gaino E 1998. Reproductive strategies of Mycale contarenii (Porifera: Demospongiae). Mar. Biol. 131: 319-327.

Devos C 1965. Le bourgeonnement externe de l'éponge Mycale contarenii. Bull. Mus. Nat. Hist. Nat. Paris 37: 548-555.

Diaz JP 1979. Variations, differentiations et functions des categories cellulaires de la demosponge d'eaux saumatres, Suberites massa, Nardo, au cours du cycle biologique annuel et dans des conditions experimentales. D. Phil. Thesis, Université Montpellier, $290 \mathrm{pp}$.

Dolmatov IY 2014. Asexual Reproduction in Holothurians. Sci. World J. http://dx.doi.org/10.1155/2014/527234

Elvin DV 1976. Seasonal growth and reproduction of an intertidal sponge Haliclona permolis (Bow.). Biol. Bull. 151: 108-125.

Ereskovskii AV 1999. Development of Haplosclerida sponges (Demospongiae, Ceractinomorpha). Russ. J. Mar. Biol. 25: 361-371.

Ereskovsky AV 2000. Reproduction cycles and strategies of cold-water sponges Halisarca dujardini (Demospongiae, Dendroceratida), Myxilla incrustans and Iophon piceus (Demospongiae, Poecilosclerida) from the White Sea. Biol. Bull. 198: 77-87.

Ereskovsky AV 2010. The comparative embryology of sponges. Springer Verlag, Dordrecht, Heidelberg, London, New York. 329 pp.

Ereskovsky AV \& Tokina DB 2007. Asexual reproduction of homoscleromorph sponges (Porifera; Homoscleromorpha). Mar. Biol. 151: 425-434.

Ereskovsky AV \& Gonobobleva EL 2000. New data on embryonic development of Halisarca dujardini Johnston, 1842 (Demospongiae: Halisarcida). Zoosyst. 22: 355-368.

Ereskovsky AV, Dubios M, Ivanisevic J, Gazave E, Lapebie P, Tokina D, \& Pérez T 2013. Pluriannual study of the reproduction of two Mediterranean Oscarella species (Porifera, Homoscleromorpha): cycle, sex-ratio, reproductive effort and phenology. Mar. Biol. 160: 423-438.

Fell PE 1970. The natural history of Haliclona ecbasis de Laubenfels, a siliceous sponge of California. Pacific Sci. 24: 381-386. 
Fell PE 1974. Diapause in the gemmules of the marine sponge Haliclona loosanoffi, with a note on the gemmules of Haliclona oculata. Biol. Bull. 147: 333-351.

Fell PE 1976. The reproduction of Haliclona loosanoffi and its apparent relationschip to water temperature. Biol. Bull. 150: 200-210.

Fell PE 1993. Porifera. In: Asexual propagation and reproductive strategies. Adiyodi KG, Adiyodi RG, eds. pp. 1-44. Oxford and IBH, New Delhi.

Fell PE, Lewandrowski KB, \& Lovice M 1979. Postlarval reproduction and reproductive strategy in Haliclona loosanoffi and Halichondria sp. In: Biologie des Spongiaures. Lévi C, Boury-Esnault N, eds., pp. 113-122. Coll. Internat. Paris. C.N.R.S. 291, Paris.

Franke HD 1999. Reproduction of the Syllidae (Annelida: Polychaeta). Hydrobiologia 402: 39_ 55.

Fromont J 1988. Aspects of the reproductive biology of Xestospongia testudinaria (Great Barrier Reef). Proc Sixth Int Coral Reef Symp 2:685-691.

Fromont J 1990. A taxonomic study of tropical marine sponges (Porifera: Demospongiae: Haplosclerida and Petrosida) using morphological, chemical and reproductive character sets. D. Phil. Thesis, James Cook University, Australia. 113 pp.

Fromont J 1994a. Reproductive development and timing of tropical sponges (Order Haplosclerida) from the Great Barrier Reef, Australia. Coral Reefs 13: 127-133.

Fromont J 1994b. The reproductive biology of tropical species of Haplosclerida and Petrosida on the Great Barrier Reef. In: Sponges in time and space; Biology, Chemistry, Paleontology. van Soest RWM, van Kempen ThMG, eds., pp. 307-312. Braekman, J. C. A.A. Balkema Publ, Rotterdam.

Fromont J \& Bergquist PR 1994. Reproductive biology of three sponges species of the genus Xestospongia (Porifera: Demospongiae: Petrosiida) from the Great Barrier Reef. Coral Reefs 13: 119-126.

Gaino E, Scalera-Liaci L, Sciscioli M, \& Corriero G 2006. Investigation of the budding process in Tethya citrina and Tethya aurantium (Porifera, Demospongiae). Zoomorph. 125: 8797.

Gaino E, Mercurio M, Sciscioli M, \& Corriero G 2009. Choanocyte chambers in unreleased buds of Tethya seychellensis (Wright, 1881) (Porifera, Demospongiae). Ital. J. Zool. 76: 6469.

Giesel JT 1972. Sex ratio, rate of evolution and environmental heterogeneity. Am. Nat. 106: 380387.

Hammel JU, Herzen J, \& Beckmann F 2009. Sponge budding is a spatiotemporal morphological patterning process: insights from synchrotron radiation-based xray microtomography into the asexual reproduction of Tethya wilhelma. Front. Zool. 6:19, doi:10.1186/1742-99946-19.

Hartman W 1958. Natural history of the marine sponges of southern New England. Bull. Peabody Mus. Nat. Hist. Yale Univ. 12: 1-155.

Herlant-Meewis H 1948. La gemmulation chez Suberites domuncula. Arch. Anat. Microsc. Morph. Exp. 37: 289-322.

Hill MS, Hill AL, Lopez J, Peterson KJ, Pomponi S, Diaz MC, Thacker RW, Adamska M, Boury-Esnault N, Cardenas P. et al. 2013. Reconstruction of Family-Level Phylogenetic Relationships within Demospongiae (Porifera) Using Nuclear Encoded Housekeeping Genes. PLoS One. 8:e50437.

Hogg JJ 1967. Approaches to the systematics of the Demospongiae. D. Phil. Thesis, University 
of Auckland, Auckland, New Zealand. 145 pp.

Hoppe WF 1988. Reproductive patterns in three species of large coral reef sponges. Coral Reefs 7: 45-50.

Ilan M \& Loya Y 1988. Reproduction and settlement of the coral reef sponge Niphates sp. (Red Sea). In: Proceedings of the 6th international coral reef symposium. Vol. 2, Choat, JH, Barnes D, et al. eds. Australia, pp. 745-749.

Ilan M \& Loya Y 1990. Sexual reproduction and settlement of the coral reef sponge Chalinula $s p$. from the Red Sea. Mar. Biol. 105: 25-31.

Ilan M, Jochen G, \& Van Soest RWM 2004. Taxonomy, reproduction and ecology of new and known Red Sea sponges. Sarsia 89: 388-410.

Ivanisevic J, Pérez T, Ereskovsky AV, Barnathan J, \& Thomas OP 2011a. Lysophospholipids in the Mediterranean Sponge Oscarella tuberculata: Seasonal Variability and Putative Biological Role. J. Chem. Ecol. 37: 537-545.

Ivanisevic J, Thomas OP, Pedel L, Pénez N, Ereskovsky AV, Culioli G, \& Pérez T 2011b. Biochemical trade-offs: evidence for ecologically linked secondary metabolism of the sponge Oscarella balibaloi. PLos One. 6(11): e28059. doi:10.1371/journal.pone.0028059.

Ivanova-Kazas OM 1977. Asexual reproduction of animals. Leningrad Univ. Press. Leningrad. $240 \mathrm{pp}$.

Jackson JBC \& Coates AG 1986. Life cycles and evolution of clonal (modular) animals. Phil. Trans. Roy. Soc. Lond. 313: 7-22.

Kasyanov VL 2001. Reproductive Strategy of Marine Bivalves and Echinoderms. Enfield Sci Publishers, New York. 229 pp.

Korotkova GP 1988a. Integrative mechanisms and morphogenesis (to problem of onthogenesis evolution). Zhur. Obshey Biol. 69: 464-475.

Korotkova GP 1988b. Peculiarities of organization and types of the development in sponges. In: Porifera and Cnidaria: Modern and perspective investigations. Koltun, VM, Stepanjants SD, eds., pp. 34-40. USSR Academy of Sciences, Zoological Institute publ. Moscow.

Lawrence JM \& Herrera J 2000. Stress and deviant reproduction in Echinoderms. Zool. Stud. 39: 151-171.

Leong W \& Pawlik JR 2011. Comparison of reproductive patterns among 7 Caribbean sponge species does not reveal a resource trade-off with chemical defenses. J. Exp. Mar. Biol. Ecol. 401: 80-84.

Lepore E, Sciscioli M, Gherardi M \& Scalera Liaci L 1995. The ultrastructure of the mature oocyte and the nurse cells of the Ceractinomorpha Petrosia ficiformis. Cah. Biol. Mar. 36: $15-20$.

Lévi C 1956. Ètude des Halisarca de Roscoff. Embryologie et systematique des Démosponges. Arch. Zool. Exp. Gén. 7: 3-181.

Leys SP \& Degnan BM 2002. Embryogenesis and metamorphosis in a haplosclerid demosponge: gastrulation and transdifferentiation of larval ciliated cells to choanocytes. Invert. Biol. 121: 171-189.

Lindquist N, Bolser R, \& Laing $\mathrm{K}$ 1997. Timing of larval release by two Caribbean demosponges. Mar. Ecol. Prog. Ser. 155: 309-313.

Llodra ER 2002. Fecundity and Life-history Strategies in Marine Invertebrates. Adv. Mar. Biol. 43: 87-170.

Lucas CH, Graham WM, \& Widmer C 2012. Jellyfish life histories: role of polyps in forming 
and maintaining scyphomedusa populations. Adv. Mar. Biol. 63: 133-196.

McCormack GP, Erpenbeck D \& van Soest RWM 2002. Major discrepancy between phylogenetic hypotheses based on molecular and morphological criteria within the Order Haplosclerida (Phylum Porifera: Class Demospongiae). J. Zool. Syst. Evol. Res. 40: 237240.

Maldonado M 2007. Intergenerational transmission of symbiotic bacteria in oviparous and viviparous demosponges, with emphasis on intracytoplasmicallycompartmented bacterial types. J. Mar. Biol. Ass. UK 87: 1701-1713.

Maldonado M \& Riesgo A 2009. Gametogenesis, embryogenesis, and larval features of the oviparous sponge Petrosia ficiformis (Haplosclerida, Demospongiae). Mar. Biol. 156: 2118-2197.

Maynard Smith J 1978. Optimization Theory in Evolution. Ann. Rev. Ecol. Syst. 9: 31-56.

McDonald JI 2002. The Population ecology of three inter-tidal sponge species from Darwin Harbour, Australia. D. Phil. Thesis, Northern Territory University, Australia. 188 pp.

Mercurio M, Corriero G, \& Gaino G 2007. A 3-year investigation of sexual reproduction in Geodia cydonium (Jameson 1811) (Porifera, Demospongiae) from a semi-enclosed Mediterranean bay. Mar. Biol. 151: 1491-1500.

Mercurio M, Corriero G, Gherardi M, Baldacconi \& Gaino E 2013. Sexual reproduction in Sarcotragus spinosulus from two different shallow environments. Mar. Ecol. 34: 394408.

Merejkowsky CS 1878. Les Eponges de la mer Blanche. Mém. Acad. Impér. Sci. St. Pétersbourg 26: $1-51$.

Merejkowsky CS 1879. Reproduction des éponges par bourgeonnement extérieur. Arch. Zool. Exp. Gén. 8: 417-433.

Morrow C \& Carsenas P 2015. Proposal for a revised classification of the Demospongiae (Porifera). Front. Zool. 12:7, DOI: 10.1186/s12983-015-0099-8

O'Dea A 2006. Asexual propagation in the marine bryozoan Cupuladria exfragminis. J. Exp. Mar. Biol. Ecol. 335: 312-322.

Olive PJW 1995. Annual breeding cycles in marine invertebrates and environmental temperature: probing the proximate and ultimate causes of reproductive synchrony. J. Therm. Biol. 20: 79-90.

Oliver J \& Babcock RC 1992. Aspects of fertilisation ecology of broadcast spawning corals: sperm dilution effects and in situ measurements of fertilisation. Biol. Bull. 183: 409-418.

Pérez T, Ivanisevic J, Dubois M, Pedel L, Thomas OP, Tokina D, \& Ereskovsky AV 2011. Oscarella balibaloi, a new sponge species (Homoscleromorpha: Plakinidae) from the Western Mediterranean Sea: cytological description, reproductive cycle and ecology. Mar. Ecol. 32: 174-187.

Piscitelli M, Corriero G, Gaino E \& Uriz MJ 2011. Reproductive cycles of the sympatric excavating sponges Cliona celata and Cliona viridis in the Mediterranean Sea. Invert. Biol. 130: 1-10.

Plotkin AS \& Ereskovsky AV 1997. Ecological aspects of asexual reproduction of the White Sea Sponge Polymastia mammillaris (Demospongiae, Tetractinomorpha) in Kandalaksha Bay. In: Modern problems of Poriferan biology. Ereskovsky AV, Keupp H, Kohring HR, eds., pp. 127-132. Berliner Geowiss Abh, Freie Univ, Berlin. 
Pomponi SA \& Meritt DW 1990. Distribution and life history of the boring sponge Cliona trutti in the Upper Chesapeake Bay. In: New Perspectives in Sponge Biology. Rützler K, ed., pp. 384-390. Smithsonian Inst, Press, Washington

Purcell JE, Atienza D, Fuentes V, Olariaga A, Tilves U, Colahan C, \& Gili J-M 2012. Temperature effects on asexual reproduction rates of scyphozoan species from the northwest Mediterranean Sea. Hydrobiol. 690: 169-180.

Raleigh J, Redmond NE, Delehan E, Torpey S, van Soest RWM, et al. 2007. Mitochondrial cytochrome oxidase 1 phylogeny supports alternative taxonomic scheme for marine Haplosclerida. J. Mar. Biol. Ass. UK 87: 1577-1584.

Redmond NE, van Soest RWM, Kelly M, Raleigh J, Travers SAA \& McCormack GP 2007. Reassessment of the classification of the Order Haplosclerida (Class Demospongiae, Phylum Porifera) using 18S rRNA gene sequence data. Mol. Phylogenet. Evol. 43: 344352.

Redmond NE, van Soest RWM, Kelly M, Raleigh J, Travers SAA, Bradshaw B, Vartia A, Stephens KM \& McCormack GP. 2011. Phylogenetic relationships of the marine Haplosclerida (Phylum Porifera) employing ribosomal (28S rRNA) and mitochondrial (cox1, nad1) gene sequence data. PLoS One 6:e24344.

Redmond NE, Morrow CC, Thacker RW, Diaz MC, Boury-Esnault N, Cárdenas P, Hajdu E, Lôbo-Hajdu G, Picton BE, Pomponi SA, Kayal E. \& Collinsal AG 2013. Phylogeny and Systematics of Demospongiae in Light of New Small Subunit Ribosomal DNA (18S) Sequences. Integr. Comp. Biol. 53: 388-415.

Reverter M, Perez T, Ereskovsky A, \& Banaigs B 2016. Secondary Metabolome Variability and Inducible Chemical Defenses in the Mediterranean Sponge Aplysina cavernicola. J. Chem. Ecol. 42: 60-70.

Reuter M \& Kreshchenko N 2004. Flatworm asexual multiplication implicates stem cells and regeneration. Can. J. Zool. 82: 334-356.

Riesgo A \& Maldonado M 2008. Differences in reproductive timing among sponges sharing habitat and thermal regime. Invert. Biol. 127: 357-367.

Riesgo A, Novo M, Sharma PP, Peterson M, Maldonado M, \& Giribet G 2014. Inferring the ancestral sexuality and reproductive condition in sponges (Porifera). Zool. Script. 43: 101-117.

Saller U 1990. Formation and construction of asexual buds of the fresh-water sponge Radiospongilla cerebellata (Porifera, Spongillidae). Zoomorphol. 109: 295-301.

Sarà M 1988. Two new species of Tethya (Porifera, Demospongiae) from New Caledonia. Bull. Mus. Nat. Hist. Nat. Paris 4: 651-659.

Sarà M, Corriero G, \& Bavestrello G 1993. Tethya (Porifera, Demospongiae) species coexisting in a Maldivian coral lagoon: taxonomic, genetic and ecological data. Pub. Staz. Zool. Napoli I. Mar. Ecol. 14: 341-355.

Sarà A, Cerrano C, \& Sarà M 2002. Viviparous development in the Antarctic sponge Stylocordyla borealis Loven, 1868. Polar Biol. 25: 425-431.

Scalera Liaci L, Sciscioli M, Matarrese A, \& Giove C 1971. Osservazioni sui cicli sessuali di alcune Keratosa (Porifera) e loro interesse negli studi filogenetici. Atti Soc. Peloritana Sci. Fis. Mat. Natur. 17: 33-52.

Scalera Liaci L, Sciscioli M, \& Matarrese A 1973. Raffronto tra il comportamento sussuale di alcune Ceractinomorpha. Riv. Biol. 66: 135-162

Sewell MA \& Levitan DR 1992. Fertilisation success in a natural spawning of the dendrochirote 
sea cucumber Cucumaria miniata. Bull. Mar. Sci. 51: 161-166.

Simonini R \& Prevedelli D 2003. Effects of temperature on two Mediterranean populations of Dinophilus gyrociliatus (Polychaeta: Dinophilidae). I. Effects on life history and sex ratio. J. Exp. Mar. Biol. Ecol. 291: 79-93.

Simpson TL 1984. The cell biology of sponges. Springer, Berlin, Heidelberg, New York. 662 pp. Singh A \& Thakur NL 2015. Field and laboratory investigations of budding in the tetillid sponge Cinachyrella cavernosa. Invert. Biol. 134: 19-30.

Smith LC 1986. Larval release in the sponge Callyspongia diffusa. In: Coral Reef Population Biology, Jokiel PL, Richmond RH, Rogers RA, eds., pp. 286-291. Sea Grant Coop. Rep. Univ, Hawaii.

Stephens KMM, Galvin J, Lawless A \& McCormack GP 2013. Reproductive cycle and larval characteristics of the sponge Haliclona indistincta (Porifera: Demospongiae). J. Mar. Biol. Ass. UK. 93: 899-907.

Strathmann RR 1978. The evolution and loss of feeding larvae stages of marine invertebrates. Study of larval settlement in the sea. Evolution 32: 894-906.

Szmant AM 1986. Reproductive ecology of Caribbean reef corals. Coral Reefs 5: 43-54.

Teixido N, Gilia J-M, Uriz M-J, Gutt J \& Arntz WE 2006. Observations of asexual reproductive strategies in Antarctic hexactinellid sponges from ROV video records. Deep-Sea Res. II. 53: 972-984.

Topsent E 1888. Sur les gemmules de quelques silicisponges marines. Compt. Rend. Acad. Sci. Paris 106: 1298-1300.

Tuzet O 1932. Recherches sur l'histologie des éponges Reniera elegans et $R$. simulans. Arch. Zool. Exp. Gén. 74: 169-192.

Vacelet J 1999. Planktonic armoured propagules of the excavating sponge Alectona (Porifera: Demospongiae) are larvae: evidence from Alectona wallichii and A. mesatlantica sp. nov. Mem. Queens. Mus. 44: 627-642.

van Soest RWM 1991. Demosponge higher taxa classification re-examined. In: Fossil and recent sponges. Reitne J, Keupp H, eds., pp. 54-71. Springer-Verlag, Berlin.

Wapstra M \& van Soest RWM 1987. Sexual reproduction, larval morphology and bechaviour in Demosponges from the southwest of the Netherlands. In: Taxonomy of Porifera. Vol. 13. Boury-Esnault N, Vacelet J, eds., 281-307. NATO ASI Ser: Springer, Berlin.

Whalan S, Battershill C, \& de Nys R 2007. Sexual reproduction of the brooding sponge Rhopaloeides odorabile. Coral Reefs 26: 655-663.

Wulf JL 1991. Asexual fragmentation, genotype success, and population dynamics of erect branching sponges. J. Exp. Mar. Biol. Ecol. 49: 227-247.

Wulf JL 1995. Effects of a hurricane on survival and orientation of large erect coral reef sponges. Coral Reefs 14: 55-61.

Zarrouk S, Ereskovsky AV, Ben Mustapha K, El Abed A \& Pérez T 2013. Sexual Reproduction of Hippospongia communis (Lamarck, 1814) (Dictyoceratida, Demospongiae): comparison of two populations living under contrasted environmental conditions. Mar. Ecol. 34: 432-442. 


\section{Figure legends}

Fig. 1. Specimen of Haliclona fulva, in situ, (A) without buds, in June 2008, and (B) with buds, in February 2008. Scale bars $=30 \mathrm{~mm}$. b, buds; o, oscula.

Fig. 2. Diagram of the reproductive cycle of Haliclona fulva.

Fig. 3. Oogenesis in Haliclona fulva, histological section (Masson-Goldner's trichrome hematoxylin staining). A. The mesohyl with oocytes at previtellogenic stage. B. Previtellogenic oocyte phagocyting the cells (arrowhead). C. The mesohyl with the eggs. D. Egg of H. fulva. Scale: $A=50 \mu \mathrm{m} ; \mathrm{B}, \mathrm{D}=20 \mu \mathrm{m} ; \mathrm{C}=100 \mu \mathrm{m}$. cc, choanocyte chambers; eg, egg; exc, exhalant canal; gc, granular cell; n, nucleus; oo, oocytes; s, spicules.

Fig. 4. Reproductive efforts of Haliclona fulva. A. Boxplot distribution of reproductive efforts during oogenesis and corresponding water temperatures during the study. B. Boxplot distribution of reproductive efforts during budding.

Fig. 5. Buds of Haliclona fulva. A. Buds in vivo at different stages of development. B. Buds in vivo at last stages of development. C. Semithin section of early bud. D. Semithin section of the bud at last stage. Inset: TEM micrograph of collagen bundles in the mesohyl of a bud. Scale: $\mathrm{A}=5 \mathrm{~mm}, \mathrm{~B}=1.5 \mathrm{~mm}, \mathrm{C}=100 \mu \mathrm{m}, \mathrm{D}=150 \mu \mathrm{m}$, Inset=4 $\mu \mathrm{m}$. b, buds; cb, collagen bundles; cc, choanocyte chambers; ch, choanocytes; ep, exopinacocytes; gc, granular cells; l, lacuna; mgc, microgranular cells; o, osculum; sb, symbiotic bacteria; ss, spongin of spicules.

Fig. 6. TEM images of the choanocytes in buds from individuals of Haliclona fulva. A. The aggregate of separated choanocytes in early bud. B. Choanocyte chamber with central cell in the bud at last stage. C. Central cell inside of a choanocyte chamber. Scale: $A, B=5 \mu \mathrm{m} ; C=2 \mu \mathrm{m}$. c, canal in a central cell cytoplasm; ce, central cell; ch, choanocyte; f, flagella of choanocytes; mv, microvilli; n, nucleus; sb, symbiotic bacteria.

Fig. 7.TEM images of the cells in buds from individuals of Haliclona fulva. A. Exopinacocytes. B. Microgranular cells. C. Granular cell. D. Archaeocytes. E. Lophocyte. F. Sclerocytes. G. Endopinacocyte. Scale: $\mathrm{A}-\mathrm{D}, \mathrm{F}, \mathrm{G}=5 \mu \mathrm{m} ; \mathrm{E}=10 \mu \mathrm{m}$. af, axial filament of a spicule; ar, archaeocytes; ch, choanocyte; en, endopinacocyte; ex, exopinacocytes; g, granule; lo, lophocyte; mgc, microgranular cells; n, nucleus; nu, nucleolus; sb, symbiotic bacteria; sc, sclerocytes; ss, spongin of spicule; $v$, vacuole.

\section{Table legend}

Table 1. The number of individuals of Haliclona fulva collected during the sampling period for histological investigation. 
Fig. 1

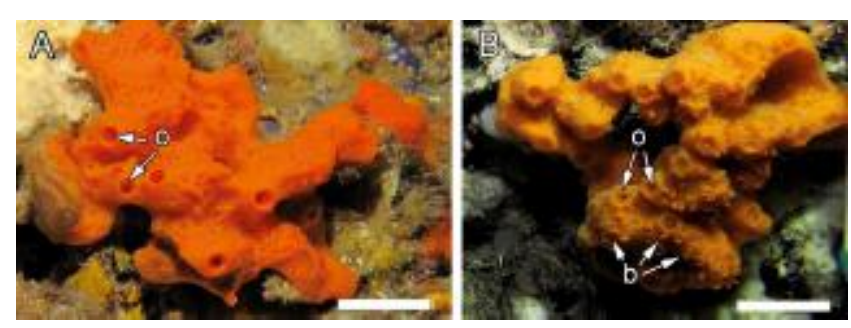


Fig. 2

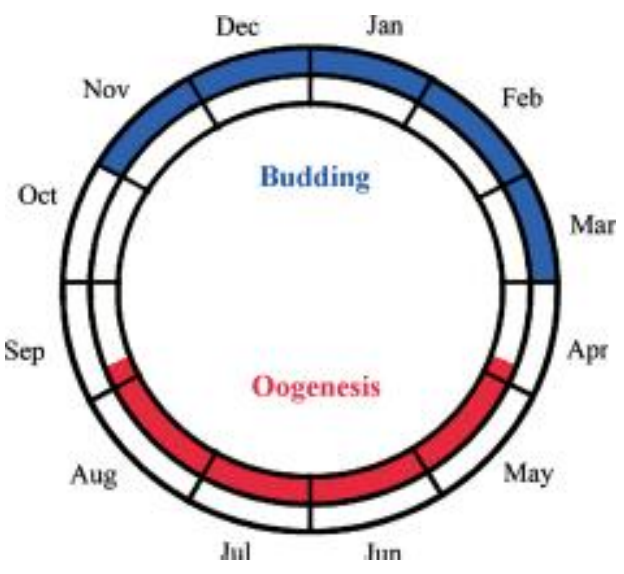




\section{Fig. 3}
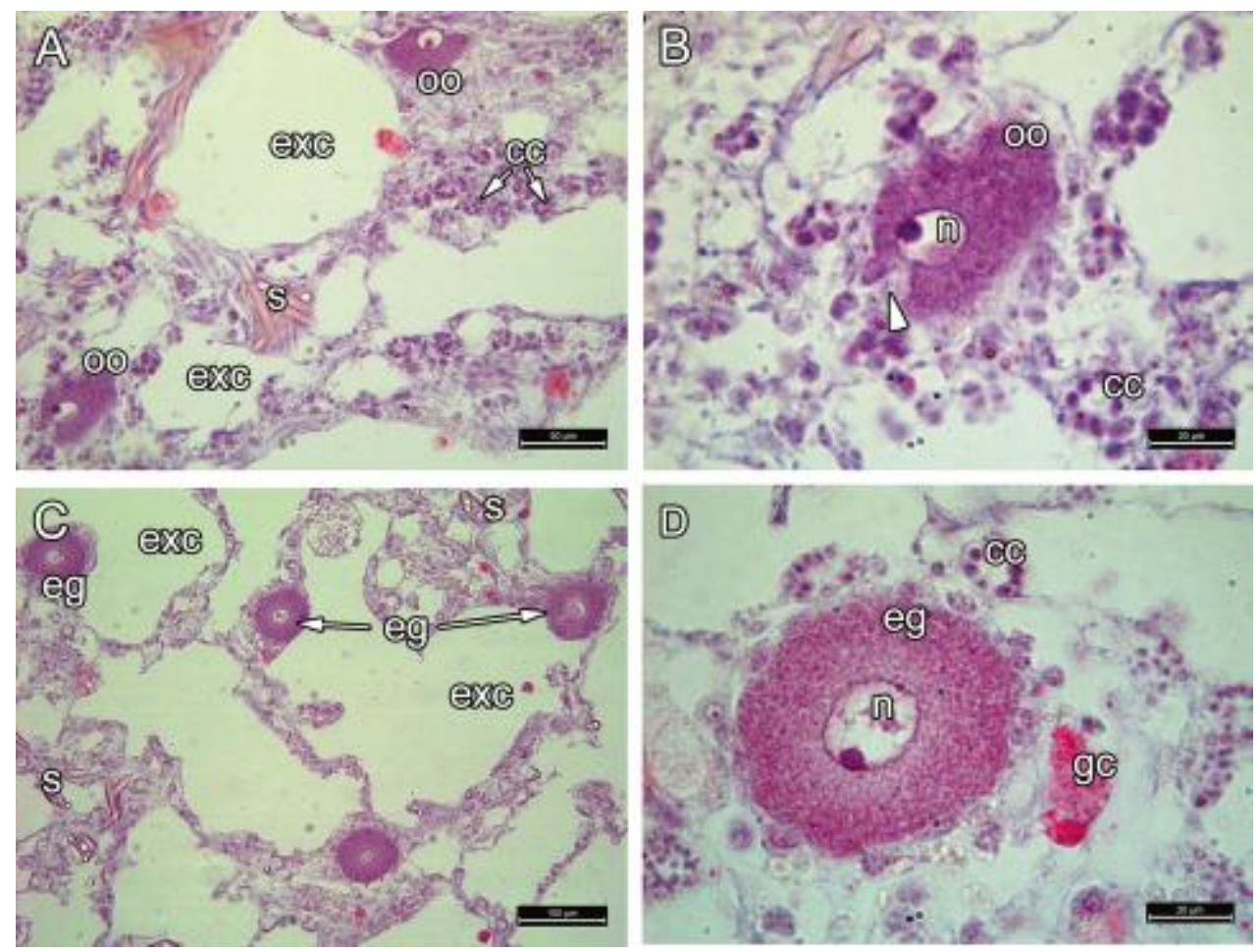
Fig. 4
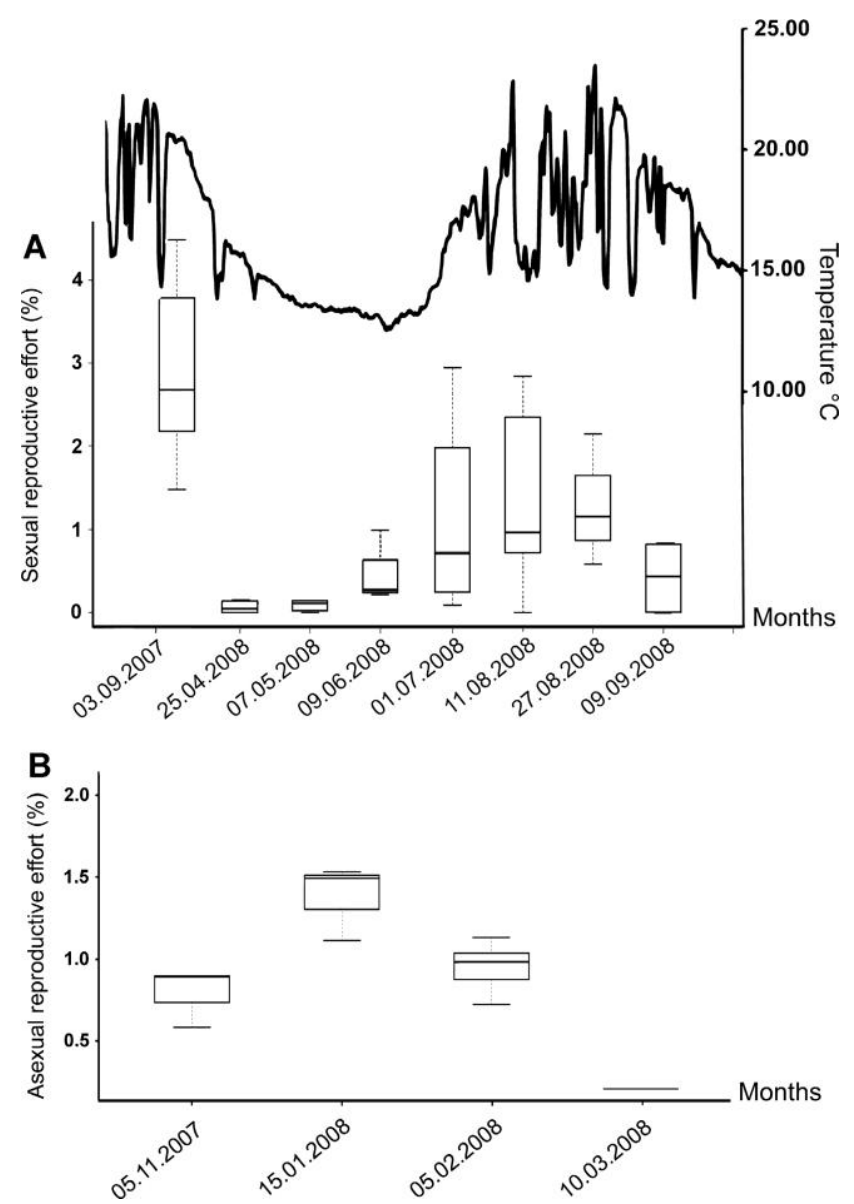
Fig. 5
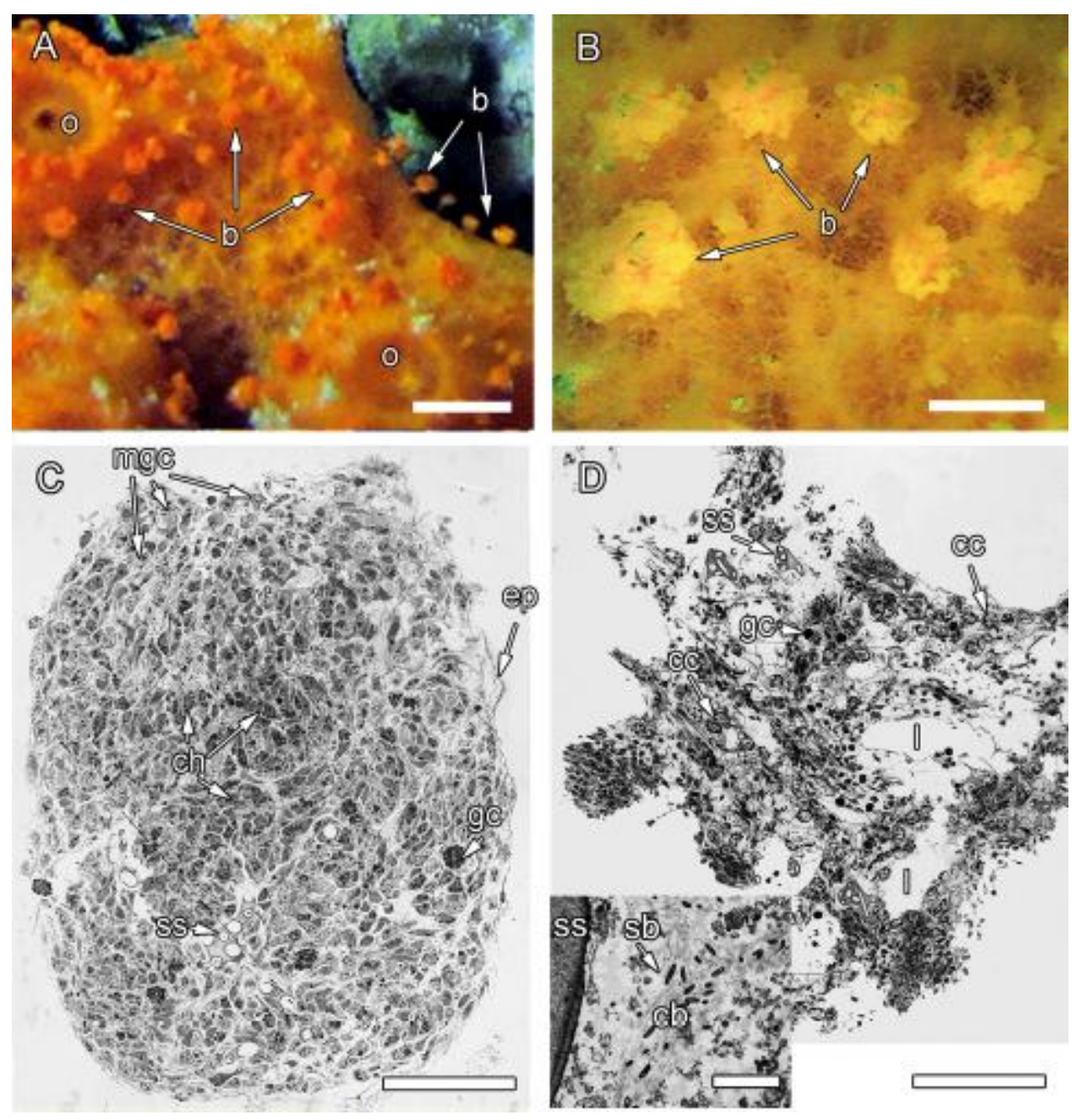
Fig. 6
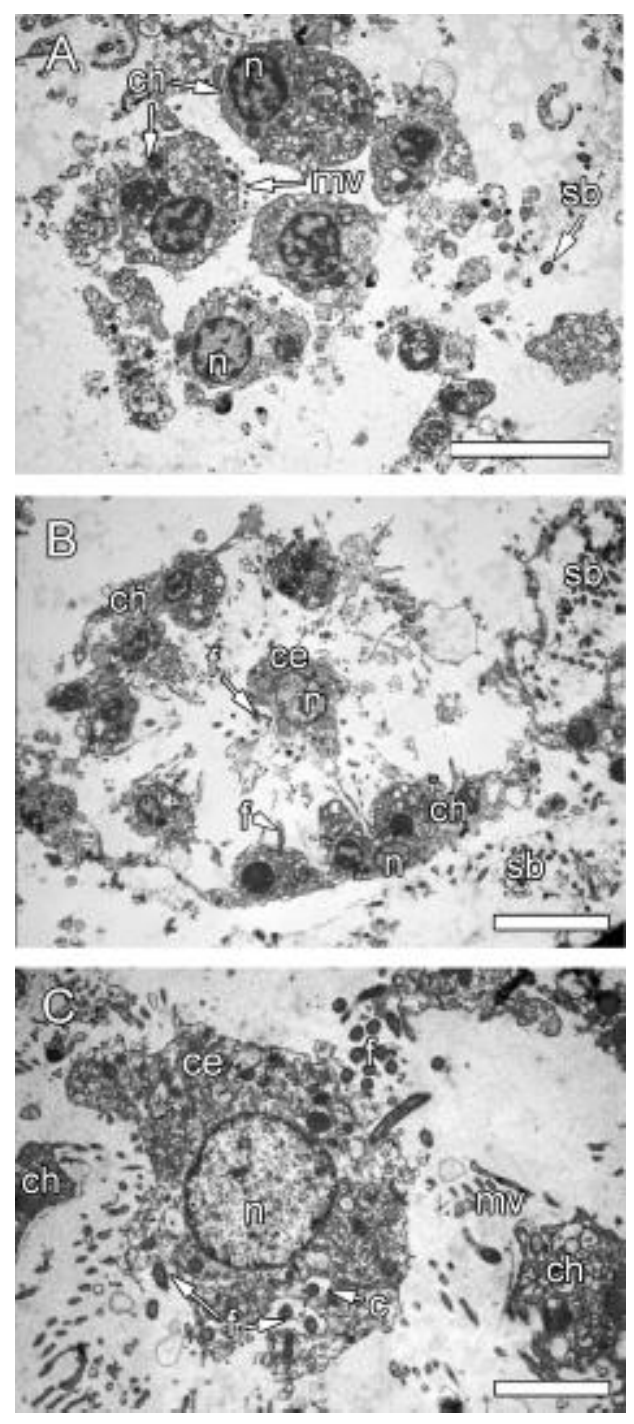
Fig. 7
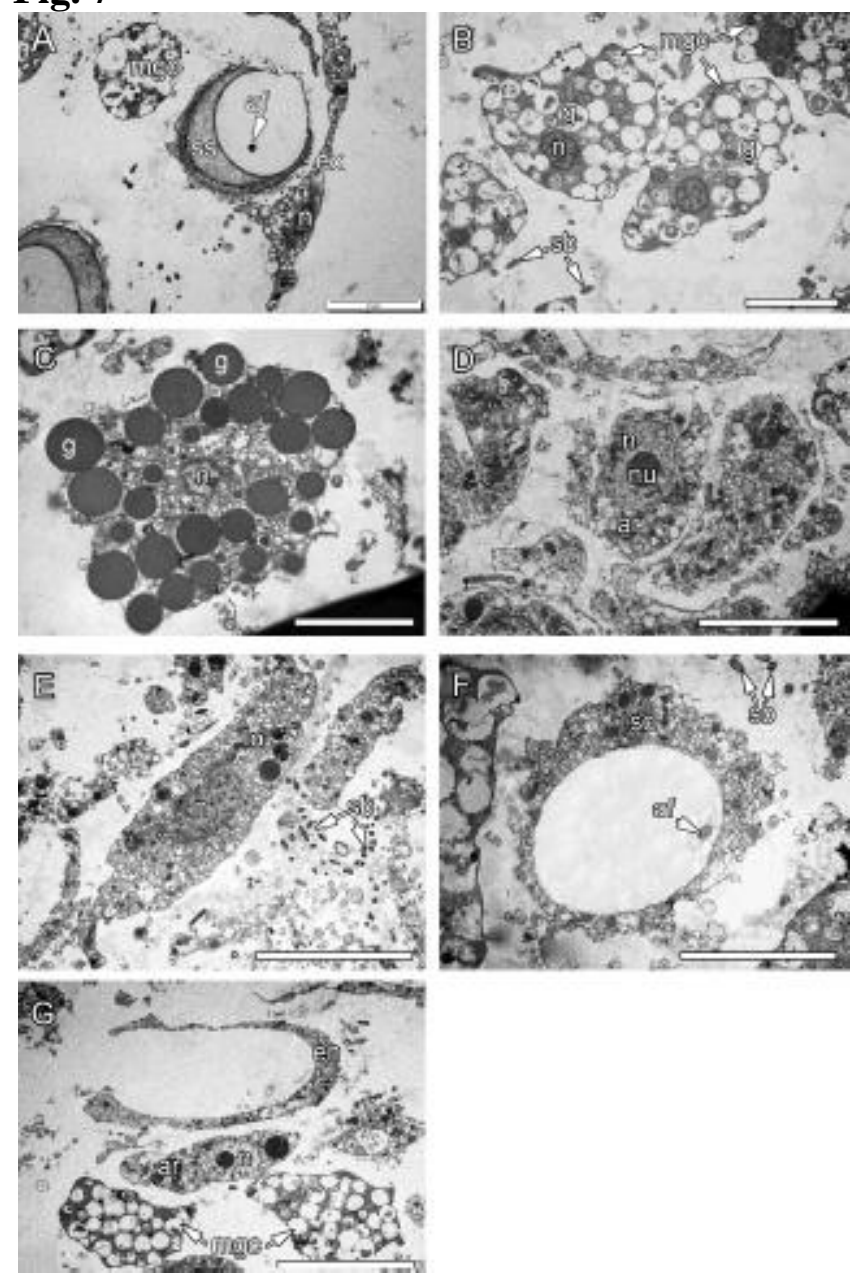
Table 1

\begin{tabular}{lccccc}
\hline \hline Date & No. of sponges & Budding & Oogenesis & Embryogenesis & Spermatogenesis \\
\hline September 3, 2007 & 7 & No & 7 & No & No \\
November 5, 2007 & 10 & No & No & No & No \\
December 5, 2007 & 9 & 9 & No & No & No \\
January 15, 2008 & 5 & 5 & No & No & No \\
February 5, 2008 & 6 & 6 & No & No & No \\
March 10, 2008 & 4 & No & No & No & No \\
April 25, 2008 & 6 & No & 4 & No & No \\
May 7, 2008 & 6 & No & 4 & No & No \\
June 9, 2008 & 5 & No & 5 & No & No \\
June 19, 2008 & 6 & No & 4 & No & No \\
July 1, 2008 & 6 & No & 6 & No & No \\
August 11, 2008 & 5 & No & 5 & No & No \\
August 27, 2008 & 5 & No & 5 & No & No \\
September 9, 2008 & 5 & No & No & No & No \\
October 14, 2008 & 4 & 6 & No & 0 & 0 \\
November 18, 2008 & 6 & 4 & No & 44 & \\
December 8, 2008 & 4 & 25 & & & \\
January 15, 2009 & 4 & & & &
\end{tabular}

